Grasz, S., T. Keisanen, F. Oloff, M. Rauniomaa, I. Rautiainen \& M. Siromaa (toim.) 2020. Menetelmällisiä käänteitä soveltavassa kielentutkimuksessa - Methodological Turns in Applied Language Studies. AFinLAn vuosikirja 2020. Suomen soveltavan kielitieteen yhdistyksen julkaisuja n:o 78. Jyväskylä. s. 155-173.

Esa Lehtinen \& Elina Salomaa

Jyväskylän yliopisto

\title{
Digitaalinen diskurssi työelämän kontekstissa - menetelmällisiä haasteita ja ratkaisuehdotuksia
}

\begin{abstract}
Digital technologies have become an inseparable part of most workplace activities. In this article, we discuss the study of digital work in the context of complex organizational practices. We lay out some methodological challenges and suggest some possible solutions to them. Firstly, we contend that we should take into consideration the multimedial nature of organizational practices. Secondly, several kinds of data - such as video-recordings of face-toface encounters, screenshots from digital platforms, ethnographic observation and interviews - may be needed to gain an understanding of such practices. Thirdly, the analyst needs to pay attention to the affordances of the media that the participants display an orientation to through their action. In our conclusions, we discuss the consequences of our approach for publishing and application of research results.
\end{abstract}

Keywords: digital discourse, workplace, multimediality

Asiasanat: digitaalinen diskurssi, työelämä, multimediaalisuus 
156 DIGITAALINEN DISKURSSI TYÖELÄMÄN KONTEKSTISSA MENETELMÄLLISIÄ HAASTEITA JA RATKAISUEHDOTUKSIA

\section{Johdanto}

Digitalisaatiolla on ollut käänteentekevä vaikutus työelämään. Yhä suurempi osa työelämän vuorovaikutuksesta tapahtuu $\mathrm{mm}$. erilaisten digitaalisten alustojen, käyttöjärjestelmien, sosiaalisen median ja sähköpostin välityksellä. Kun esimerkiksi matkalasku tehtiin aikaisemmin paperilomakkeella, joka lähetettiin hallintovirkailijalle, nykyään työntekijä hoitaa yhä suuremman osan prosessista digitaalisessa itsepalvelujärjestelmässä (Arminen \& Poikus 2009). Kokouksissa taas voidaan hyödyntää chattia (Markman 2006) tai videoneuvottelulaitteistoja (Oittinen ja Piirainen-Marsh 2015). Pohdimme tässä artikkelissa digitalisoituvan työelämän tutkimista erityisesti diskurssintutkimuksen näkökulmasta.

Aikaisempi työelämän digitaalista diskurssia tarkasteleva tutkimus on suurelta osin ollut vertailevaa: on tarkasteltu sitä, miten digitaalisen diskurssin kielelliset ja vuorovaikutukselliset piirteet eroavat perinteisemmistä kielenkäytön muodoista. Keskustelunanalyysia hyödyntävissä tutkimuksissa on tarkasteltu sitä, miten (erityisesti tekstipohjaisen) digitaalisen diskurssin vuorottelu- ja sekvenssijärjestelmä eroaa kasvokkaisesta vuorovaikutuksesta. Markman $(2006,2009)$ tarkastelee tutkimuksessaan chat-pohjaisia kokouksia ja kiinnittää huomiota siihen, miten chatin kvasisynkroninen luonne vaikuttaa vuorotteluun. Hän osoittaa, miten kokousten avaaminen ja lopettaminen vaatii enemmän työtä, kun kasvokkaiselle vuorovaikutukselle ominainen mahdollisuus seurata keskustelukumppanin vuoroa sen tuottamisen aikana puuttuu (Markman 2009). Skovholt ja Svennevig (2013) taas ovat tarkastelleet sähköpostivuorovaikutusta työpaikalla ja havainneet, miten sen normit eroavat kasvokkaisesta vuorovaikutuksesta. Ensinnäkin vastaamisessa voi olla pitkiäkin viiveitä ilman että viiveen ongelmallisuuteen orientoidutaan. Toiseksi myös vastaamatta jättäminen on tietyissä tapauksissa ongelmatonta. Sosiolingvistisessä tutkimuksessa taas on tarkasteltu digitaalisen diskurssin tyyliä ja kohteliaisuuskeinoja suhteessa kasvokkaiseen vuorovaikutukseen. Esimerkiksi Darics (2010) osoittaa, miten chat-pohjaisissa kokouksissa tarvitaan erityisiä kohteliaisuusstrategioita, joilla kompensoidaan kasvokkaisen kontaktin puutetta.

Vertailevat tutkimukset ovat tuottaneet arvokasta tietoa siitä, millaista teknologiavälitteinen vuorovaikutus työpaikoilla on luonteeltaan. Toisaalta kuitenkin viime aikoina on nostettu esiin näkökantoja, jotka monipuolistavat kuvaa digitaalisen vuorovaikutuksen roolista osana työtä. Ensinnäkin on kyseenalaistettu eronteko digitaalisen ja ei-digitaalisen vuorovaikutuksen välillä. Arminen, Licoppe ja Spagnolli (2016) huomauttavat, ettei vuorovaikutuksen välitteisyys koske pelkästään digitaalista vuorovaikutusta. Kasvokkainenkin vuorovaikutus on esimerkiksi kielen ja kehon välittämää. Näin ollen viestintäteknologiat olisi nähtävä yhtenä välitteisyyden muotona muiden joukossa. Toiseksi, kuten Orlikowski ja Scott (2016) huomauttavat, digitaalista työtä ei voi erottaa ei-digitaalisesta työstä. Nykypäivän työelämän käytänteet ovat kauttaaltaan digitaalisuuden kyllästämiä. Kolmanneksi (ks. esim. Boczkowski \& 
Orlikowski 2004; Darics 2015) työelämän käytänteet ovat kompleksisia: niissä käytetään rinnakkain ja peräkkäin esimerkiksi puhetta, eleitä, tekstiä, kuvia ja videoita. Boczkowski ja Orlikowski (2004) pitävätkin tärkeänä, että työelämän digitaalisia käytänteitä tarkastellaan laajempien organisatoristen käytänteiden kontekstissa, osana kompleksista toimintaa.

Tässä metodologisessa artikkelissa otamme lähtökohdaksi ajatuksen digitaalisista käytänteistä osana laajempaa organisatorista kontekstia. Nähdäksemme tämä näkökulma asettaa diskurssintutkijan uudenlaisten haasteiden eteen. Tavoitteenamme tässä artikkelissa on nostaa esiin erityisesti aineiston keräämiseen ja analyysiin liittyviä haasteita ja tarjota niihin ratkaisuehdotuksia. Tarkastelemme kolmenlaisia haasteita. Ne koskevat ensinnäkin tällaisten käytänteiden tarkastelussa tarvittavia käsitteitä, toiseksi sitä, millaisia aineistoja tutkijan olisi hyvä kerätä, ja kolmanneksi sitä, millaisia ilmiöitä tutkija valitsee analyysinsa fokukseen. Ehdotamme olennaiseksi käsitteeksi multimediaalisuutta ja pohdimme monipuolisen aineiston keräämistä, jonka avulla multimediaalista toimintaa voidaan tarkastella. Lisäksi esitämme, että analyysia kannattaa tehdä aineistolähtöisesti, kiinnittää huomioita niihin eri medioiden ominaisuuksiin, jotka vuorovaikutuksen osallistujat itse osoittavat relevanteiksi.

Lähestymme teemaa erään tutkimusaineistoistamme poimimamme esimerkkitapauksen näkökulmasta. Aluksi kuitenkin, seuraavassa luvussa, avaamme teoreettisia lähtökohtiamme ja keskeisiä analyyttisia käsitteittämme. Sen jälkeen esittelemme aineistomme ja käsiteltävän esimerkkitapauksen. Analyysissa pohdimme edellä mainittuja haasteita tämän esimerkkitapauksen kautta. Loppuluvussa teemme yhteenvedon ratkaisuehdotuksistamme ja pohdimme myös, mitä metodologisista ratkaisuista seuraa yhtäältä tutkimuksen julkaisemisen ja toisaalta soveltamisen näkökulmasta.

\section{Teoreettisia lähtökohtia ja käsitteitä}

Teoreettisesti sitoudumme näkemykseen diskurssista sosiaalisena toimintana. Tämä näkemys yhdistää useimpia diskurssianalyysin muotoja (esim. Fairclough 2003; Jokinen, Juhila \& Suoninen 1993) ja etnometodologista keskustelunanalyysia (ten Have 2007). Tällöin ihmiset nähdään toimijoina, jotka sekä kuvaavat maailmaa että pyrkivät vaikuttamaan siihen, ja niin tehdessään hyödyntävät luovasti erilaisia kontekstuaalisia resursseja - kuten kielen ja vuorovaikutuksen rakenteita, kehoaan, tilaa, liikettä, digitaalisia teknologioita. Toimijat tällöin myös itse osoittavat, mitä kontekstin piirteitä he pitävät relevantteina. Tutkimuksen tavoitteena on tällöin kuvata, miten toimintaa tuotetaan kontekstuaalisten resurssien avulla. Edellä mainittuihin suuntauksiin kuuluvissa tutkimuksissa on kuitenkin eroja muun muassa sen suhteen, millaista toimintaa niissä tarkastellaan ja miten kontekstuaaliset resurssit otetaan tutkimuksessa huomioon. Tarkennamme seuraavaksi omaa näkökulmaamme suhteessa 
158 DIGITAALINEN DISKURSSI TYÖELÄMÄN KONTEKSTISSA MENETELMÄLLISIÄ HAASTEITA JA RATKAISUEHDOTUKSIA

näihin kysymyksiin. Esittelemme tässä luvussa, mitä tarkoitamme organisatorisilla käytänteillä, multimediaalisuudella ja medioiden tarjoumilla, Suhteutamme samalla näitä käsitteitä omaan näkökulmaamme, digitaaliseen diskurssiin osana työelämän kompleksisia käytänteitä.

Aluksi on syytä tehdä ero yhtäältä vuorovaikutuskäytänteiden, toisaalta organisatoristen käytänteiden välille. Vuorovaikutuskäytänteillä tarkoitamme esimerkiksi vuorottelukäytänteitä kuten vuoron ottamista tai seuraavan puhujan osoittamista tai sekventiaalisia käytänteitä kuten kysymistä ja vastaamista. Vuorovaikutuskäytänteet toimivat mikrotasolla, ja ne ovat siinä mielessä yleisiä, että niitä voidaan hyödyntää monenlaisissa konteksteissa. Organisatoriset käytänteet taas ovat laajempia toiminnallisia kokonaisuuksia, jotka kytkeytyvät organisatorisiin tavoitteisiin. Tällaisia ovat esimerkiksi organisaation toiminnan reflektoiminen ja arviointi tai organisaation (strategisten) tavoitteiden suunnittelu. Esimerkiksi Llewellyn (2010) osoittaa, miten työhaastattelun vuorovaikutuskäytänteet, erityisesti kysyminen ja vastaaminen, kytkeytyvät organisatorisiin käytänteisiin kuten työntekijöiden arviointiin. Hän kiinnittää huomiota myös siihen, miten työhaastattelu on vain osa tuota arviointiprosessia. Pälli ja Lehtinen (2014) taas tarkastelevat ehdotuksia ja niihin vastaamista osana organisatorista tavoitteenasettelua kehityskeskusteluvuorovaikutuksessa.

Organisaatiovuorovaikutuksen tutkimuksessa on viime vuosina yleistynyt multimodaalinen lähestymistapa, joka ottaa huomioon puhetilanteessa myös osallistujien keholliset toiminnot ja erilaiset materiaaliset artefaktit. Multimodaalinen keskustelunanalyysi on tuottanut arvokasta tietoa nimenomaan erilaisista organisaatiovuorovaikutuksen mikrokäytänteistä, kuten kokouksen avaamisesta tai samanlinjaisuuden tuottamisesta, ja teknologian roolista osana noita käytänteitä. Tutkijat ovat valottaneet esimerkiksi tietokoneen roolia kokouskeskustelussa, kun he ovat voineet tarkastella osallistujien orientoitumista jaettuun näyttöön (Asmuß \& Oshima 2012; Oittinen \& Piirainen-Marsh 2015). Näissä multimodaalisuudesta ammentavissa tutkimuksissa teknologiaa on käsitelty tiettyyn rajattuun puhetilanteeseen kietoutuvana materiaalisena artefaktina.

Jos kuitenkin haluamme kohdistaa katseemme vuorovaikutuskäytänteitä laajempiin organisatorisiin käytänteisiin, on nähdäksemme tilanteita tarkasteltava paitsi multimodaalisina myös multimediaalisina. Tämä tarkoittaa, että ensinnäkin on syytä erottaa usein synonyymisesti käytetyt moodin ja median käsitteet toisistaan. Kress ja van Leeuwen (2001) viittaavat moodilla muotoon, jossa merkitykset tuotetaan tilanteessa. Esimerkiksi konekirjoitus ja käsinkirjoitus ovat eri moodeja, samoin kuvat, liikkuvat kuvat, eleet ja ilmeet. Moodit eivät kuitenkaan ilmesty tyhjästä, vaan ne materialisoituvat väistämättä erilaisissa artefakteissa. Esimerkiksi valokuva voi välittyä albumin, sanomalehden tai vaikkapa puhelimen näytön kautta. Näitä materiaalisia kokonaisuuksia Kress ja van Leeuwen (2001: 22) kutsuvat medioiksi.

Toiseksi on syytä painottaa, että Armisen ym. (2016) tavoin pidämme kaikkea kommunikatiivista toimintaa välitteisenä - siis tavalla tai toisella medioituna. Siinä 
missä aiemmassa tutkimuksessa digitaalista vuorovaikutusta on pidetty perinteisemmistä vuorovaikutusmuodoista poikkeavana juuri sen medioituneen luonteen takia, me näemme, että kyse on pikemmin siitä, että vuorovaikutustoiminnot voivat olla eri tavoin välitteisiä. Kun lähestymme organisaatiotilanteita multimediaalisesta näkökulmasta, keskeistä on ennen kaikkea se, millaisia mahdollisuuksia ja rajoituksia erilaiset mediat tarjoavat käyttäjälleen. Näihin käyttömahdollisuuksiin viitataan tavallisesti havaintopsykologiasta lainatulla tarjouman (tai affordanssin, engl. affordance) käsitteellä. Perustavana ajatuksena on, että medioiden ominaisuudet muotoilevat niiden käyttäjien mahdollisuutta toimintaan. (Hutchby 2001.) Yhtäältä tarjoumat on nähty varsin konkreettisina teknologian ominaisuuksina, kuten erilaisina nappeina tai näyttöinä, jotka mahdollistavat esimerkiksi kommentoimisen tai viestistä tykkäämisen. Toisaalta tarjoumia on tarkasteltu abstraktimpina toiminnan mahdollisuuksina. Digitaalisen teknologian keskeisimpinä tarjoumina pidetään esimerkiksi mahdollisuutta jakaa, tallentaa ja etsiä viestejä (Bucher \& Helmond 2018).

Multimodaalisella lähestymistavalla tutkijat ovat lähestyneet digitaalisia medioita siitä näkökulmasta, miten niihin suuntaudutaan kasvokkaisessa vuorovaikutuksessa. Me sen sijaan lähestymme kaikkia medioita lähtökohtaisesti samanarvoisina ja otamme huomioon, että digitaaliset alustat eivät usein rajaudu tilaan tai aikaan. Sen vuoksi onkin tarkasteltava sitä, miten digitaalisten alustojen tarjoumat ikään kuin ylittävät alustan omat rajat, ja miten ne yhdistyvät muihin medioihin ja niiden tarjoumiin. On tärkeä huomata, että vaikka tarjoumat mahdollistavat ja rajoittavat tietynlaisia toimintoja, ne eivät yksin sanele sitä, mihin mediaa käytetään. Niin käyttäjä kuin käyttökontekstikin vaikuttavat aina siihen, miten tarjoumia hyödynnetään kussakin tilanteessa (Hutchby 2001; Bucher \& Helmond 2018). Tässä mielessä olennaiseksi tutkimuskohteeksi muodostuu organisatorisen kontekstin ja medioiden suhteessa mahdollistuva toiminta.

\section{Esimerkkitapauksen kuvaus}

Havainnollistamme menetelmällisiä haasteita yhden esimerkkitapauksen avulla. Tämä esimerkkitapaus on mielenkiintoisella tavalla kompleksinen: siinä digitaaliset käytänteet ja perinteisemmät mediat kietoutuvat yhteen. Esimerkkiaineisto on erään organisaation kehittämishankkeesta, jossa työntekijöiden valmennukseen erikoistuneen verkoston tavoitteena on tukea uuden toiminnanohjausjärjestelmän käyttöönottoa. Työryhmä työskentelee sekä erilaisten digitaalisten alustojen välityksellä että kasvokkaisissa työpajoissa. Tässä artikkelissa hyödynnämme videonauhoitusta eräästä työpajasta, digitaaliselta alustalta kerättyä materiaalia ja kuvia työpajan aikana käytetyistä paperidokumenteista. Kuvaamme aineistoa tarkemmin seuraavassa jaksossa menetelmällisten haasteiden esittelyn yhteydessä. 
Tässä artikkelissa keskitymme yhteen hankkeen etenemisen kannalta olennaiseen institutionaaliseen tehtävään, jonka projektin osallistujat suorittavat kasvokkaisen tapaamisen aikana. Tehtävässä osallistujia pyydetään arvioimaan omaa osaamistaan ja pohtimaan, mitkä osa-alueet vaativat vielä kehittämistä. Tehtävänantoon ja sen suorittamiseen hyödynnetään digitaaliseen fasilitointiin kehitettyä Howspace-alustaa, jota käytetään myös monenlaisiin muihin tehtäviin, esimerkiksi työpajojen agendan organisoimiseen, informoimiseen ja erilaisten hanketta koskevien dokumenttien säilyttämiseen. Lisäksi alusta mahdollistaa osallistujien välisen keskustelun, kommentoimisen ja esimerkiksi toisten kommenteista tykkäämisen. Työpajassa on mukana kahdeksan osallistujaa, joista kuusi on samassa tilassa ja kaksi etäyhteyden päässä. Mukana on kaksi fasilitaattoria, joista erityisesti toisella (Eveliina) on tilanteessa keskeinen rooli. Analyysissa painottuu väistämättä enemmän kasvokkaisten kuin etäosallistujien rooli, koska etäosallistujista ei ole videokuvaa.

Tarkoituksenamme tässä artikkelissa on kiinnittää huomiota menetelmällisiin haasteisiin, ei tehdäyksityiskohtaista empiiristä analyysia. Analyysia tehdään sillä tarkkuudella kuin on tarpeen edellä mainittujen haasteiden havainnollistamiseksi; sitä voisi kuvata karkeaksi teksti-ja vuorovaikutusanalyysiksi, jossa sekä kielenkäyttöä että ei-kielellisiä tekoja lähestytään sosiaalisena toimintana. Vuorovaikutusanalyysissa käytämme melko karkeaa litteraatiota, joka pohjautuu keskustelunanalyyttiseen litterointitapaan (esim. Seppänen 1997). Päällekkäispuhuntojen alku on merkitty kaarisulkeilla. Analyysin kannalta relevantit keholliset toiminnot on merkitty puherivin päälle. Niiden alku on merkitty *-merkillä. ${ }^{1}$

\section{Digitaalisten käytänteiden tutkimiseen liittyvät haasteet esimerkin valossa}

Esittelemme seuraavaksi lyhyesti kolme keskeistä haastetta, jotka liittyvät digitaalisen diskurssin tutkimiseen työelämän konteksteissa. Nämä kaikki haasteet ja niihin tarjoamamme ratkaisuehdotukset kytkeytyvät edellä mainittuihin näkökantoihin, joiden mukaan digitaalista vuorovaikutusta on lähestyttävä yhtenä välitteisen vuorovaikutuksen muotona muiden joukossa ja kiinnitettävä huomiota siihen, että digitaalisuus on kauttaaltaan läsnä organisatorisissa käytänteissä.

1 Analyysin tarkkuustaso on toki myös erillinen metodologinen haaste, joka on erityisen relevantti tutkimuksissa, joissa hyödynnetään monenlaisia aineistoja. Tähän haasteeseen liittyy myös litteraation tarkkuus ja muutenkin tavat esittää erilaisia aineistoja. Näitä haasteita emme kuitenkaan tässä artikkelissa käsittele. 


\subsection{Multimediaaliset organisatoriset tilanteet}

Havainnollistamme aluksi, miksi digitaalista diskurssia voi olla vaikea - jopa mahdoton - tarkastella irrallisena siitä organisatorisesta tilanteesta, johon se kiinnittyy. Vaikka organisaatiot hyödyntävät erilaisia viestintävälineitä silloin, kun osallistujat viestivät etäällä toisistaan, asettuvat teknologiat usein myös osaksi kasvokkaistilanteita. Lisäksi yhtä digitaalista alustaa voidaan käyttää tilanteesta riippuen joko etänä tai esimerkiksi osana kokouskäytänteitä. Esimerkkitapauksessamme käytössä oleva Howspace on juuri tällainen alusta. Seuraava kuvakaappaus (kuva 1) on digitaaliselta alustalta.

\section{Valmentajien kompetenssi ja osaamisen kehittämisen tarpeet (taso nyt ja mitä tarvitset?)}

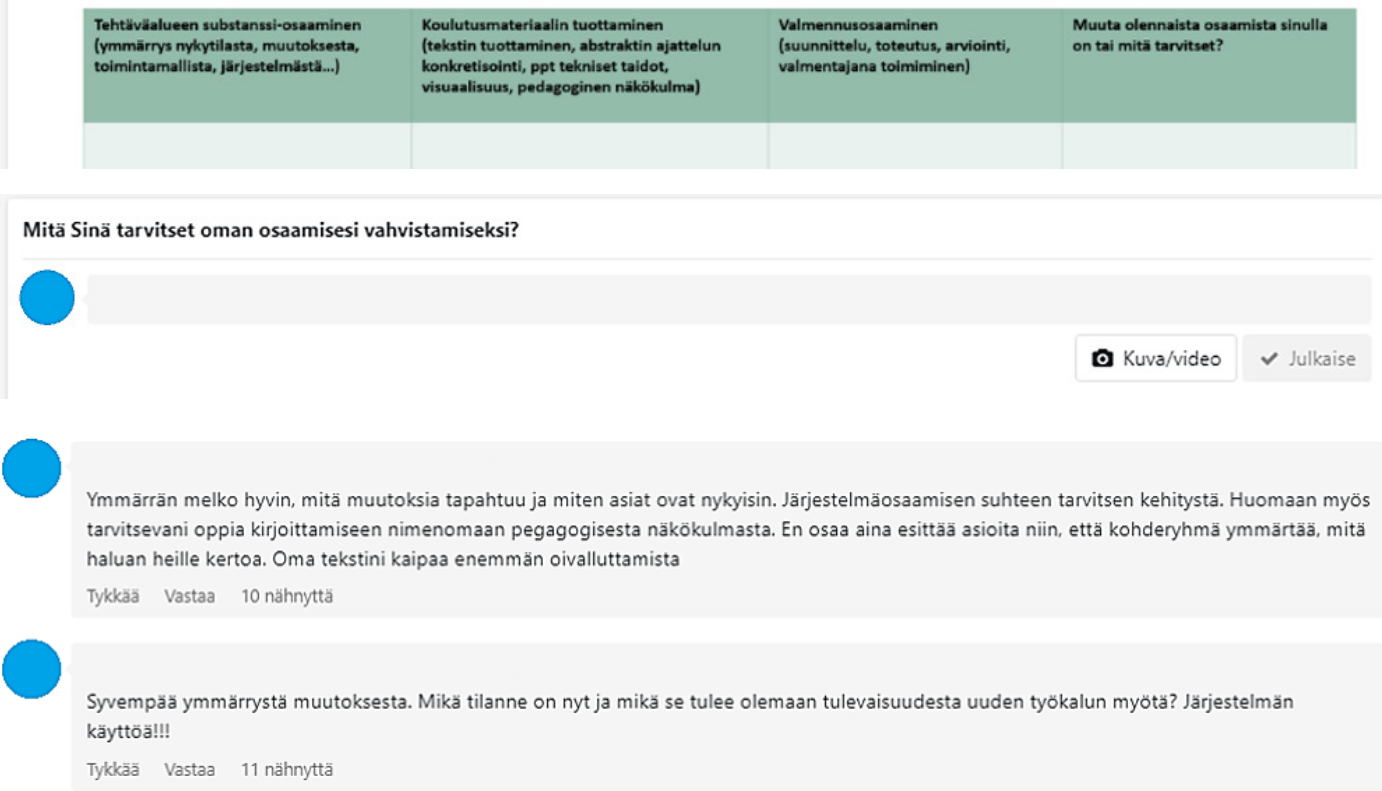

KUVA 1. Tehtävänanto ja kommentit Howspace-alustalla

Esimerkissä vuorovaikutus alustalla näyttää rakentuvan tehtävänannosta ja siihen vastaamisesta. Tehtävänanto esitetään tavallaan kahteen kertaan. Aluksi alustalla on tehtävämatriisi, jonka päällä on kaksiosainen tehtävänanto (taso nyt ja mitä tarvitset?). Sen jälkeen alustan kommenttikentässä tehtävänantoa täsmennetään jättämällä nykytaso tehtävänannosta pois (mitä Sinä tarvitset osaamisesi vahvistamiseksi?). Kuten esimerkistä on nähtävissä, osallistujat suuntautuvat tehtävänantoon 
162 DIGITAALINEN DISKURSSI TYÖELÄMÄN KONTEKSTISSA -

MENETELMÄLLISIÄ HAASTEITA JA RATKAISUEHDOTUKSIA

eri tavoin: ensimmäinen kommentoija vastaa ylempään tehtävänantoon (ymmärrän melko hyvin --- miten asiat ovat nykyisin, järjestelmäosaamisen suhteen tarvitsen kehitystä), toinen alempaan (syvempää ymmärrystä muutoksesta, järjestelmän käyttöä!!!). Huomionarvoista on se, että osallistujat eivät ole keskenään vuorovaikutuksessa, vaikka he molemmat näkevät järjestelmän käytössä kehittymisen varaa. Kommentoijat eivät asetu osoittamaan samanmielisyyttään kanssakommentoijien kanssa esimerkiksi vastaamalla toisen kommentoijan aloitukseen tai tykkäämällä tämän viestistä vaan suuntautuvat suoraan vastaamaan tehtävänantoon omasta näkökulmastaan. Olisi houkuttelevaa tehdä johtopäätös, että responssien puuttuminen johtuu siitä digitaalisessa diskurssissa yleisesti havaittavasta piirteestä, että digitaalisella alustalla vuoroihin vastaaminen ei ole samalla tavalla normatiivista kuin puhutussa vuorovaikutuksessa. Esimerkiksi Skovholt ja Svennevig (2013) ovat osoittaneet, että ellei sähköpostiviesti ole sisältänyt pyyntöä vastaanottajalle, ei tähän vastaamattomuutta tavallisesti käsitellä ongelmallisena.

Esimerkkitapauksessa on kuitenkin otettava huomioon, että tehtävänanto ja sen suorittaminen toteutetaan työpajassa, jossa suurin osa keskustelijoista on läsnä. Tällöin työpajakonteksti asettuu olennaiseksi osaksi analyysia. Pelkän digitaalisen alustan ja sen kommenttien tarkastelu antaa toiminnasta vaillinaisen kuvan, ja siksi niitä onkin syytä tarkastella osana muuta organisaation (senhetkistä) vuorovaikutusta. Videomateriaali (esim. 1) tilanteesta osoittaakin, että tehtävää ei anneta osallistujille pelkästään digitaalisella alustalla, vaan fasilitaattori (Eveliina) jakaa osanottajille tehtävämatriisin myös paperisena ja muotoilee tehtävänannon lisäksi suullisesti paperinjakotilanteessa. Videomateriaali on kuvattu kahdella kameralla. Alla olevassa kuvassa huoneen perällä olevan kameran kuva on vasemmalla, ja etuosassa olevan kameran kuva oikealla.

Esimerkki 1

01 Eveliina: mä tein tota tänne howspaceen tälle pohjan

*Eveliina ojentaa paperin Lauralle

mut mä aattelin että *mä rakastan [näitä papereita

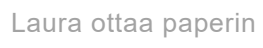

03 Laura:

[kiitos

*Eveliina ojentaa paperin Antille

04 Eveliina: ja printtien jakamista *ni voitte ihan hahmotella kynällä [siihen

05 Antti: [kiitti

*Antti, Kari, Tiia ja Rauli ryhtyvät etsimään kyniä käsiinsä

06 Eveliina: *et mikä se on se tänhetkinen fiilis, te tietysti ette voi

07 arvioida sitä tilannetta 
08

09

10 mikä se on *syksyllä mut

*Eveliina ojentaa paperin Tiialle

*mikä fiilis teil on tällä hetkellä

siitä et mitä se osaaminen mitä te kaipaisitte niin olisi

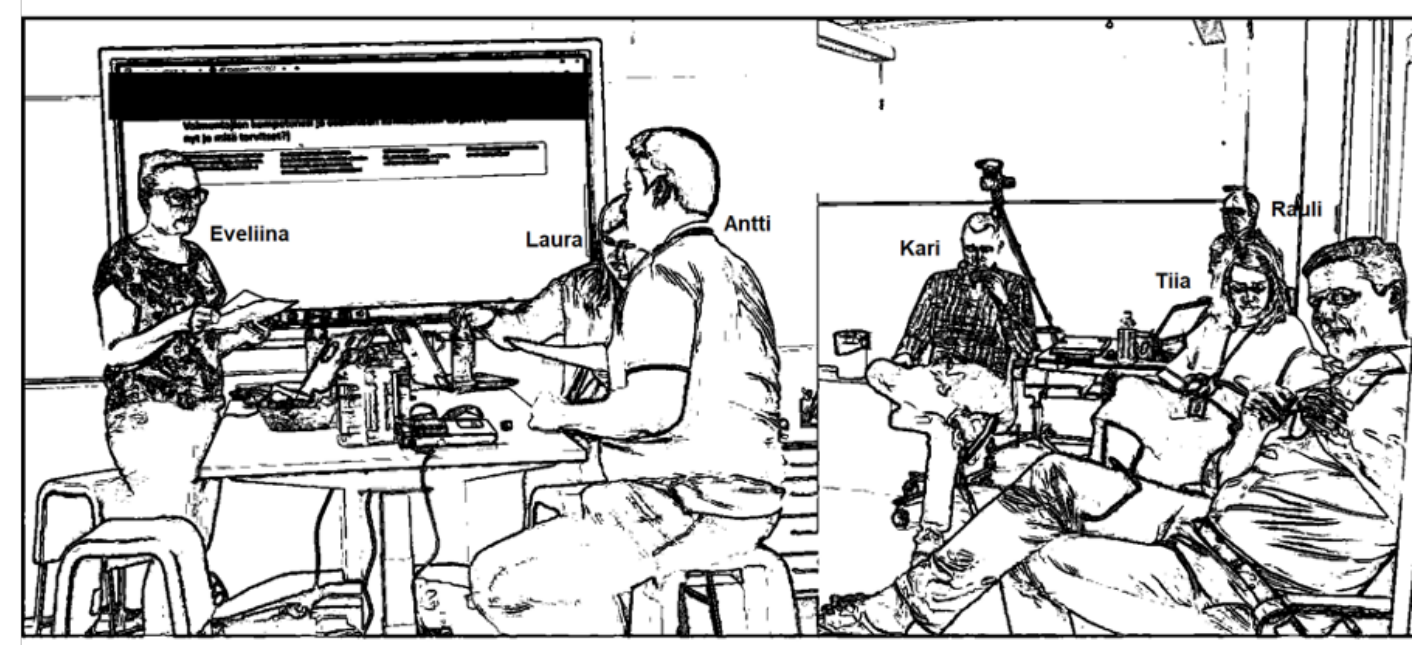

(rivejä poistettu)

*Eveliina skrollaa tehtäväkaavion

näkyviin näytöllä

11

12

Eveliina: ja nyt tota meiän etäosallistujat *sitte voitte iteksenne voitte miettiä hahmottelemaa

\section{*Eveliina vie osoittimen}

'valmentajan kompetenssi' päälle

eli me tosiaan mietitään nyt *tätä valmentajien en mä tiedä onks tää kompetenssi

\section{*Eveliina skrollaa alaspäin ja pyörittää}

osoitinta kaavion päällä

nyt huono sana mut *tää tavallaan tyhjä taulukko mikä täs howspace-sivulla on nähtävissä

ni voitte miettiä omalta osaltanne sitte myös näitä asioita

(1.0) vaikkette printtiä nyt sitte saakaan

ja pidetään tähä- käytetään tähän semmonen rauhassa kymmenen minuuttia

(rivejä poistettu: osallistujat kirjoittavat)

$$
\begin{aligned}
& \text { sit jos te ootte miettiny jo teiän niin ku sellasii } \\
& { }^{*} \text { Eveliina katsoo osallistujista läppärin näytölle }
\end{aligned}
$$




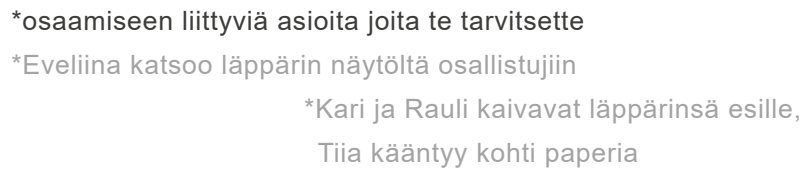

*ni kirjatkaa niitä sinne *howspaceen

Esimerkki 1 osoittaa, että tehtävänanto tuotetaan tilanteessa monin eri tavoin: digitaalinen alusta, kynä ja paperi sekä kieli ja keho tarjoavat osallistujille toisistaan poikkeavia materiaalisia resursseja osallistua meneillään olevaan toimintaan. Se tuo havainnollistavalla tavalla esiin, miten työtilanteet rakentuvat paitsi erilaisista moodeista - tekstistä, puheesta, eleistä, kuvista, äänestä - myös erilaisten medioiden kautta. Esimerkissä sekä digitaalisella alustalla että paperilla on sama tehtävämatriisi, joka koostuu kaaviosta ja kirjoitetusta tekstistä. Siirtyessään mediasta toiseen matriisi säilyttää ulkomuotonsa, mutta sen tarjoumat muuttuvat keskeisellä tavalla. Eri medioina paperinen ja digitaalinen kaavio yhtäältä mahdollistavat, toisaalta rajoittavat tietynlaisia toimintoja. Digitaalisena tehtävämatriisi voidaan esimerkiksi jakaa kaikkien, myös etäosallistujien, nähtäväksi heijastamalla se jaetulle näytölle ja skrollaamalla näkyviin (r. 11), mutta siihen ei ole mahdollista kirjoittaa, toisin kuin paperiseen kaavioon.

Armisen ym. (2016: 301) mukaan jyrkkä eronteko medioituun ja ei-medioituun viestintään voi johtaa kasvokkaisviestinnän pitämiseen standardina, jolloin erilaisten teknologisten välineiden kautta tuotettua vuorovaikutusta tarkasteltaisiin väistämättä suhteessa kasvokkaisviestintään ensisijaisena vuorovaikutusmuotona. Esimerkkitilanteessa tutkijan ei olekaan tarkoituksenmukaista tehdä erontekoa yksinomaan sen perusteella, että yksi tehtävänanto on tuotettu digitaalisesti ja toinen ei-digitaalisesti. Pikemmin tutkijan on suunnattava katseensa siihen, millaisia erilaisia tarjoumia kukin tilanteessa käytetty media tarjoaa käyttäjälleen (Hutchby 2001; Arminen ym. 2016).

Esimerkkikatkelmamme havainnollistaa, miten työelämän digitaaliset diskurssit linkittyvät erottamattomalla tavalla muihin medioihin. Uudet mediat eivät olekaan syrjäyttäneet vanhaa, vaan niitä käytetään työtilanteissa luovasti rinnakkain ja limittäin. Aikaisemmassa tutkimuksessa, jossa mediaa on tarkasteltu yhtäältä irrallisena tilanteesta, toisaalta vertailukohtana perinteisiin viestintämuotoihin, ei ole otettu riittävästi huomioon tätä työelämän käytänteiden kompleksista luonnetta. Näkemyksemme mukaan kompleksisuuteen voidaankin pureutua paremmin, jos analyysissa kiinnitetään huomiota tilanteiden multimediaalisuuteen.

\subsection{Aineisto ja sen käsittely}

Millaista aineistoa tutkijan sitten on hankittava, jotta digitaalista diskurssia voidaan lähestyä multimediaalisesta näkökulmasta? Organisaatiovuorovaikutusta on usein 
tutkittu etnometodologisen keskustelunanalyysin menetelmin, jonka periaatteiden mukaisesti tutkijalla on oltava osallistujien kanssa yhteinen pääsy niihin resursseihin, joita he hyödyntävät tulkitakseen edeltäviä vuoroja ja tuottaakseen kontekstia seuraaville vuoroille. Samalla aineiston on oltava autenttista eli sellaista, joka syntyy ilman tutkijan läsnäoloa (ten Have 2007: 68-69). Vertailevissa tutkimuksissa aineistoa on yleensä kerätty yhdenlaisesta digitaalisesta genrestä kuten sähköpostista tai chatista. Jos sen sijaan haluaa analysoida toiminnan organisoitumista kompleksisissa tilanteissa, tarvitaan monipuolisempaa aineistoa, jonka avulla voidaan päästä käsiksi niihin vuorovaikutuskäytänteiden ketjuihin ja verkostoihin, joista organisatoriset käytänteet koostuvat.

Esimerkkitapauksen aineisto on videoitu kahta videokameraa käyttäen noin kahden tunnin mittaisesta kasvokkaisesta työpajasta. Aineistoa on kerätty myös digitaaliselta alustalta kuvakaappauksina. Lisäksi otimme kuvat paperisista tehtävämatriiseista, joihin osallistujat olivat hahmotelleet vastauksiaan. Tarkastelemalla rinnakkain näitä medioita ja sitä, millaisiin vuorovaikutusfunktioihin osallistujat medioita käyttävät, pääsemme käsiksi medioiden järjestymiseen tilanteessa kahdella tavalla: Ensinnäkin voimme tutkia sitä, millä tavalla mediat järjestyvät tilanteessa suhteessa toisiinsa. Toiseksi on mahdollista tutkia myös sitä, miten erilaisia medioita hyödynnetään tietynlaisten toimintojen toteuttamiseen.

Se, mihin tiukasti perinteiseen keskustelunanalyyttisiin lähtökohtiin tukeutuva tutkija ei näinkään monipuolisella aineistolla pääse käsiksi, on syvempi ymmärrys organisatorisesta tilanteesta ja työhön liittyvistä laajemmista käytänteistä, joiden osaksi (digitaaliset) toiminnot asettuvat (Asmuß 2015). Usein kompleksiset institutionaaliset tilanteet vaativatkin sellaista organisaatioon liittyvää taustatietoa, jota ei välttämättä ole kovin helposti saatavilla: keskusteluissa viitataan aiemmin käytyihin keskusteluihin, tuleviin kokouksiin tai organisaatiota määrittäviin teksteihin, joihin tutkijalla ei ole pääsyä videoiden tai digitaalisen aineiston kautta. Lisäksi organisaation sisäiset käytännöt ja esimerkiksi konventionaaliset tavat viestiä ovat tutkijan ulottumattomissa. Seuraava esimerkkikatkelma havainnollistaa, miten tällainen haaste voidaan paikantaa.

Esimerkki 2

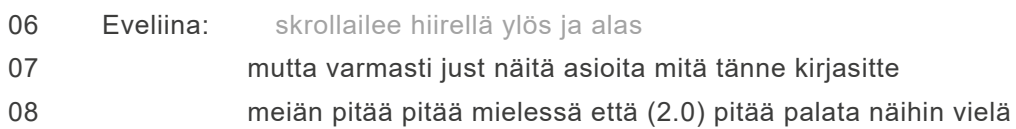

Esimerkissä osallistujat käyvät läpi digitaaliselle alustalle tulleita kommentteja fasilitaattorin johdolla. Fasilitaattorin vuoron loppuosan "pitää palata näihin vielä" ennakoi, että kommentteja tullaan tulevaisuudessa käsittelemään uudelleen jossakin yhteydessä. Vuorovaikutustilanteeseen keskittyvä tutkija ei kuitenkaan tiedä, 
166 DIGITAALINEN DISKURSSI TYÖELÄMÄN KONTEKSTISSA -

MENETELMÄLLISIÄ HAASTEITA JA RATKAISUEHDOTUKSIA

milloin tai missä tilanteessa kommentteihin palataan (vai palataanko lainkaan) eikä välttämättä pysty siksi luomaan kokonaiskuvaa organisatorisesta tehtävästä ja sen funktioista esimerkiksi jatkokäyttöä ajatellen. Tästä näkökulmasta multimediaalinen toimintaketju ikään kuin katkeaa - mutta vain tutkijan perspektiivistä.

Jotta diskurssintutkija pystyisi tarkastelemaan kokonaiskuvaa organisaation multimediaalisista käytänteistä, voisi tämän olla hedelmällistä yhtäältä kerätä aineistoa pitkittäisistä prosesseista, toisaalta ottaa analyysinsa tueksi myös etnografisia lähestymistapoja, esimerkiksi havainnointia ja haastatteluja (ks. Asmuß 2015; Asmuß \& Oshima 2018: 5), joita ei perinteisesti ole hyödynnetty vuorovaikutustutkimuksessa.Tällaisten lähestymistapojen avulla olisi mahdollista kerätä tietoa esimerkiksi siitä, millaisissa tilanteissa kommentteihin palaaminen tavallisesti tapahtuu ja miten työryhmän kommentteja mahdollisesti hyödynnetään hankkeen etenemisessä. Hankkeessamme keräämmekin pitkittäisaineistoa kyseessä olevasta kehittämishankkeesta. Lisäksi tarkoituksenamme onkin täydentää aineistoa myöhemmin myös haastatteluilla. Työelämän multimediaalisia käytänteitä tutkittaessa on kuitenkin hyväksyttävä se, että kerätty aineisto on väistämättä vain osavaihe tietyssä organisatorisessa toimintaketjussa. Se ei kuitenkaan tarkoita, etteikö tällaisia vaiheita olisi mielekästä tutkia. Päinvastoin kuvaamallamme aineistolla on mahdollista pureutua yksityiskohtaisesti toimintoihin ja käytänteisiin, jotka eri medioiden risteyksissä rakentavat näitä ketjuja.

\subsection{Medioiden ja toiminnan suhde}

Kolmas haaste, johon haluamme kiinnittää huomiota, liittyy siihen, miten tutkija pystyy hallitsemaan multimediaalista kontekstia, kun hänen on otettava huomioon yhtä aikaa lukuisia medioita ja niiden tarjoamia toimintamahdollisuuksia. Toisin sanoen kysymys on siitä, miten tutkija tunnistaa, mikä kaikki kontekstuaalinen tieto on tutkittavan ilmiön kannalta relevanttia ja miten käytetty media vaikuttaa toiminnan luonteeseen. Esimerkiksi teknologinen konteksti, organisatorinen konteksti ja tilanteen materiaaliset puitteet asettavat osallistujille erilaisia, osin päällekkäisiä, resursseja rakentaa toimintaansa. Arminen ym. (2016: 302-303) varoittavat tutkijaa liioittelemasta teknologisen kontekstin merkitystä: kaikki vuorovaikutuskäytänteet eivät juonnu teknologisesta kontekstista, vaikka keskustelu käytäisiin yksinomaan digitaalisella alustalla. Aiemmassa digitaalisen diskurssin tutkimuksessa media ja sen ominaisuudet (esimerkiksi (a)synkronisuus) on usein oletettu etukäteen, jolloin näiden ominaisuuksien nähdään väistämättä vaikuttavan vuorovaikutukseen ja sen etenemiseen (Meredith 2017: 53). Arminen ym. (2016) sekä Meredith (2017) kannustavat tutkijaa ottamaan tarjoumat analyysinsa lähtökohdaksi, jotta he voisivat ymmärtää teknologian ja sen käyttäjien suhdetta paremmin. Tällöin media ja sen ominaisuudet asettuvat kontekstiksi, jotka yhtäältä muotoilevat vuorovaikutustilannetta, toisaalta muotoutuvat siinä. Tutkijan tehtävänä onkin ennen kaikkea ekspli- 
koida, mihin tarjoumiin osallistujat itse suuntautuvat merkityksellisinä saavuttaakseen tietynlaisia päämääriä.

Esimerkkimme kohdalla olennaista voisi olla tarkastella sitä, miten osallistuvat suuntautuvat paperin, kielen, kehon ja digitaalisen alustan tarjoamiin toimintamahdollisuuksiin (ja -rajoituksiin). Kuten edellisestä esimerkistämme (1) on nähtävissä, paperi asettuu fasilitaattorin puheessa kommentin "hahmotelmaksi" (voitte hahmotella ihan kynällä siihen, r. 04) ja digitaalinen alusta arkistoksi, johon viralliset kommentit tallennetaan (kirjatkaa niitä sinne Howspaceen, r. 22). Paperin ja digitaalisen alustan tehtävänannot eivät yksinään riitä siihen, että osallistujat tarttuisivat tehtävään, vaan suullisella ja kehollisella (papereiden jakaminen) tehtävänannolla fasilitaattori tekee aloitteen, jolla kehottaa osallistujia toimimaan. Kuten osallistujien keholliset responssit esimerkissä (1) osoittavat (r. 06, 17), nimenomaan suullinen tehtävänanto saa osallistujat tarttumaan tehtävään. Samalla puhe täsmentää ja ohjeistaa, millä tavalla tarjottuja medioita toivotaan tilanteessa käytettävän (ks. Nissi \& Pälli 2020). Tehtävän antamiseen ja suorittamiseen käytetyt mediat toisin sanoen tarjoavat osallistujille erilaisia tarjoumia, joista fasilitaattori määrittelee ne, jotka ovat tarkoituksenmukaisia juuri kyseisen tehtävän suorittamiseksi. Seuraava kuvapari osoittaa medioiden erilaiset roolit tilanteessa. 
168 DIGITAALINEN DISKURSSI TYÖELÄMÄN KONTEKSTISSA MENETELMÄLLISIÄ HAASTEITA JA RATKAISUEHDOTUKSIA

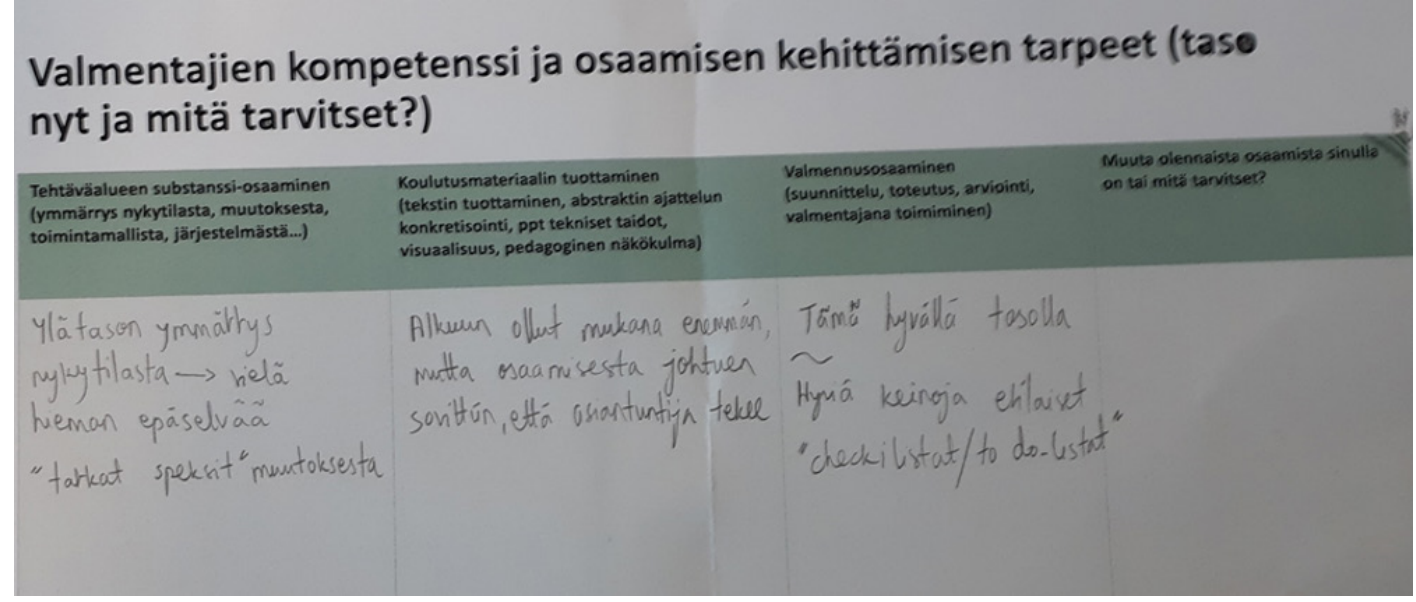

\section{Valmentajien kompetenssi ja osaamisen kehittämisen tarpeet (taso nyt ja mitä tarvitset?)}

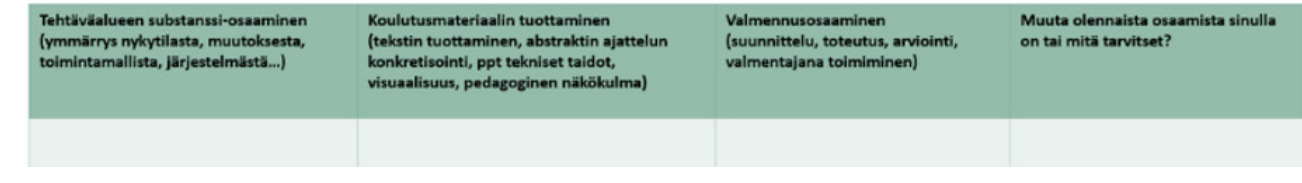

Mitä Sinä tarvitset oman osaamisesi vahvistamiseksi?

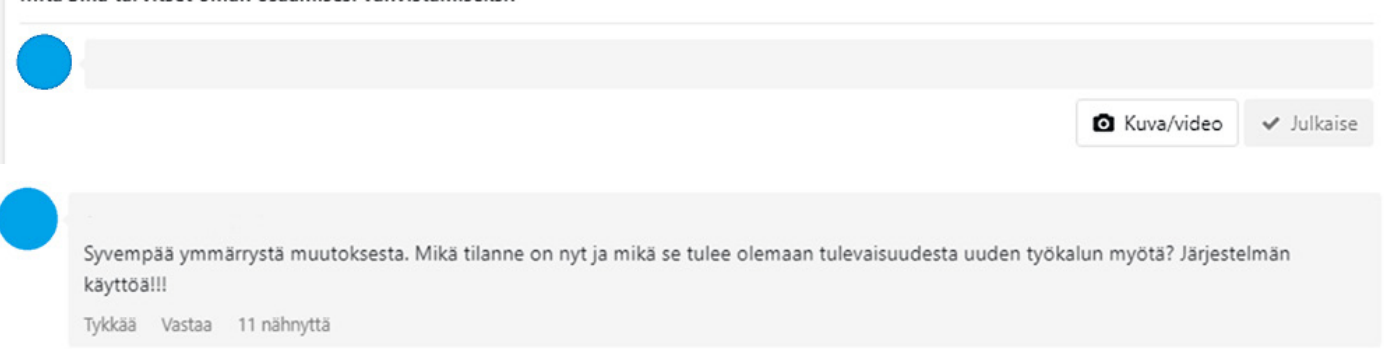

KUVA 2. Paperiseen ja digitaaliseen tehtävämatriisiin vastaaminen.

Kuvan 2 vertailu eri medioiden välillä osoittaa, miten paperi asettuu tietynlaiseksi hahmotelmaksi paitsi fasilitaattorin suullisessa tehtävänannossa myös osallistujien toiminnassa. Osallistujat voivat hyödyntää paperia alustalle kirjaamisen aikana sellaisena kirjoittamista tukevana välineenä, jonka avulla omia ajatuksia on mahdollista järjestellä helposti (ks. Sellen \& Harper 2002: 63). Tämän suhteen on olennaista se, että digitaalisella alustalla ei ole mahdollista kirjoittaa itse matriisiin vaan ainoastaan suppeamman tehtävänannon alle. Kuvassa 2 näkyykin, että paperille on hahmoteltu sekä erilaisia vahvuuksia että kehityskohteita, ja sieltä poimitaan digitaalisen alustan 
kirjaukseen nimenomaan kehitystarpeet. Ne myös muotoillaan uudelleen; esimerkiksi nuolet jäävät pois.

Seuraava esimerkki täydentää tulkintaamme. Esimerkissä osallistujat ovat kirjanneet kommenttinsa digitaaliselle alustalle ja niitä käsitellään lyhyesti kasvokkaisessa tilanteessa siten, että alusta kommentteineen on heijastettu näkyville kaikille osallistujille.

Esimerkki 3

\begin{tabular}{|c|c|}
\hline Eveliina: & skrollailee hiirellä ylös ja alas näytöllä \\
\hline \multirow[t]{3}{*}{02} & mitä te luulette pystytääks me taklaamaan nää asiat \\
\hline & *maalaa hiirellä sanat 'ymmärrys \\
\hline & muutoksesta' \\
\hline \multirow[t]{2}{*}{03} & tääl on ymmärrys *muutoksesta \\
\hline & ‘maalaa hiirellä sanan 'järjestelmäosaaminen' \\
\hline \multirow[t]{2}{*}{04} & *järjestelmäosaaminen \\
\hline & ‘maalaa hiirellä sanan 'järjestelmäosaaminen' \\
\hline & *järjestelmäosaaminen \\
\hline \multicolumn{2}{|l|}{ (poistettu rivejä) } \\
\hline 06 Eveliina: & skrollailee hiirellä ylös ja alas \\
\hline 07 & mutta varmasti just näitä asioita mitä tänne kirjasitte \\
\hline & meiän pitää pitää mielessä että (2.0) pitää palata näihin vielä \\
\hline
\end{tabular}

Esimerkissä on nähtävissä digitaaliseen alustaan suuntautuminen kahdessa tehtävässä: Ensinnäkin se toimii arkistona, jossa kommentit ovat säilössä tulevaa käyttöä varten (täytyy palata näihin vielä, r. 08). Tällainen käyttö, jossa teknologiaan suuntaudutaan sen sisällön säilyvyyden ja uudelleen haettavuuden näkökulmasta on varsin yleistä nimenomaan organisaatioissa, joissa tekstit voivat toimia virallisina dokumentteina tai muistutuksina tulevista tehtävistä (Darics 2016). Toiseksi alusta ja siellä olevat kommentit asettuvat tilanteessa sellaiseksi semioottiseksi resurssiksi, joka mahdollistaa jaetun huomion kohdistamisen tiettyihin seikkoihin (ks. Asmuß \& Oshima 2012). Fasilitaattori nostaa kommenteista keskeisenä pitämiään asioita yhteisen huomion kohteeksi sekä kielellisesti valikoimalla kommenteista yksittäisiä sanoja (ymmärrys muutoksesta, järjestelmäosaaminen) että skrollailemalla ja maalailemalla hiirellä näitä sanoja samanaikaisesti. Tällä tavalla fasilitaattori jäsentää yksilöiden ajatuksia sellaiseen muottiin, jossa ne asettuvat edustamaan työryhmää yksikkönä pikemmin kuin yksilöinä (ks. Nissi \& Pälli 2020: 18). Lisäksi digitaalisen alustan käyttö tilanteessa mahdollistaa ryhmän ajatusten tekemisen näkyväksi ja jaettavaksi myös niille, jotka eivät tilanteessa ole fyysisesti läsnä.

Esimerkki havainnollistaa, miten digitaalinen teknologia on osin vienyt paperilta sellaisia tehtäviä, joihin sitä on ennen teknologioiden yleistymistä hyödynnetty. 
170 DIGITAALINEN DISKURSSI TYÖELÄMÄN KONTEKSTISSA MENETELMÄLLISIÄ HAASTEITA JA RATKAISUEHDOTUKSIA

Esimerkiksi arkistoinnin ja dokumentin julkisen levittämisen välineenä Howspace näyttää toimivan paperia paremmin. Sen sijaan paperi näyttäisi tarjoavan tilanteessa osallistujille tarkoituksenmukaisen alustan itsenäiseen ajatusten järjestämiseen ja luonnosteluun. Esimerkki osoittaakin, että vaikka uudet mediat eivät syrjäytä vanhoja medioita, ne saattavat vaikuttaa perinteisempien medioiden tehtäviin ja rooleihin (ks. Sellen \& Harper 2002). Toisaalta on otettava huomioon myös se, että tarjoumat eivät näyttäydy kaikissa tilanteissa samanlaisina. Vaikka digitaalinen alusta mahdollistaisi esimerkiksi suoran dialogin tai toisen kommentista tykkäämisen, eivät osallistujat tartu esimerkissä näihin tarjoumiin. Samoin medioiden käyttömahdollisuudet näyttäytyvät erilaisina erilaisille käyttäjille. Tilanteessa työpajan osallistujat suuntautuvat niihin tarjoumiin, jotka parhaiten mahdollistavat annetun tehtävän suorittamisen. Fasilitaattori puolestaan käyttää medioita siitä näkökulmasta, miten ne parhaalla mahdollisella tavalla sopivat sekä tuomaan osallistujien ajatuksia esille että käsittelemään niitä. Bucher ja Helmond (2018) kannustavatkin tutkijaa herkistymään tilannekohtaisuudelle tarjoumien tarkastelussa: medioiden käyttömahdollisuudet ovat tiukasti kietoutuneita siihen, kuka teknologiaa käyttää, missä tilanteessa ja millaisiin tarkoituksiin.

\section{Päätelmät}

Olemme edellä pohtineet sitä, miten organisaatioiden digitaalisia käytänteitä voi tarkastella osana organisaation toimintaa, kaikessa kompleksisuudessaan. Suhteutimme omaa näkökulmaamme erityisesti aikaisempiin keskustelunanalyyttisiin ja sosiolingvistisiin tutkimuksiin, joissa on tarkasteltu yhtä digitaalista genreä kerrallaan, usein suhteessa kasvokkaiseen vuorovaikutukseen. Nostimme esiin kolme seikkaa: 1) On syytä kiinnittää huomiota organisaation toiminnan multimediaaliseen luonteeseen. Toimijat hyödyntävät toiminnassaan digitaalisten medioiden lisäksi, rinnalla ja limittäin niiden kanssa muita perinteisempiä medioita. 2) Tällaisen multimediaalisen toiminnan analyysiin tarvitaan monipuolisia aineistoja, jotka on kerätty erilaisista medioista. Autenttisia materiaaleja voi täydentää etnografisella havainnoinnilla ja haastatteluilla. Samalla on syytä pitää mielessä, että jotain jää väistämättä aina piiloon. 3) Analyysissa on syytä kiinnittää huomiota siihen, millä tavoin organisaation toimijat itse orientoituvat erilaisten medioiden tarjoumiin, mihin tarkoituksiin he niitä käyttävät ja miten sillä tavoin tuovat esiin medioiden mahdollisuuksien ja rajoitusten kimpun, jonka ympärillä toiminnot ja käytänteet rakentuvat, vahvistuvat ja muuttuvat. Tällaiset menetelmälliset ratkaisut vaikuttavat myös siihen, millaisessa muodossa tutkimustuloksia voi julkaista ja miten niitä voidaan soveltaa. Tässä loppuluvussa pohdimmekin vielä lyhyesti menetelmällisten ratkaisujen seurauksia. 
Kuten johdannossa totesimme, aikaisemmissa tutkimuksissa on useimmiten tutkittu jotakin tiettyä digitaalista genreä kuten sähköpostia tai chattia. Tällaisesta aineistosta löytyy yleensä joitakin usein toistuvia, esimerkiksi vuorotteluun, sekvenssirakenteeseen tai kohteliaisuuskeinoihin liittyviä ilmiöitä, joista voi kerätä laajahkon kokoelman. Tällöin on mahdollista analysoida kokoelmassa esiintyvää variaatiota ja vertailla tuloksia toisesta genrestä, esim. kasvokkaisesta kokouksesta, saatuihin tuloksiin. Jos sen sijaan haluaa tutkia digitaalisia käytänteitä osana multimediaalisia organisatorisia käytänteitä, kokoelmien kerääminen ei yleensä samassa mielessä onnistu. Tällöin on tutkimusartikkelin kokoisessa osatutkimuksessa keskityttävä tiukemmin jonkun tapauksen tutkimiseen. Tutkittavia ilmiöitä on tällöin lähestyttävä sen organisatorisen käytänteen näkökulmasta, jonka osana digitaalinen diskurssi toimii, ei niinkään joidenkin digitaalisten käytänteiden näkökulmasta sinänsä. Tämä tuo haasteita tulosten yleistämisen näkökulmasta. Nähdäksemme tällöin on liikuttava mitä-kysymyksistä yhä enemmän kohti miten-kysymyksiä. On pyrittävä osoittamaan, millä tavoin organisaatioissa niille olennaisia tehtäviä toteutetaan ja millainen rooli eri medioilla on tehtävien toteuttamisessa.

Tapaustutkimuksiin voidaan ja on pakkokin totta kai yhdistää tuloksia kokoelmapohjaisista tutkimuksista. Jos esimerkiksi ajattelee tässä artikkelissa kuvattua tapausta, jossa fasilitaattori vierittää näytöllä olevaa näkymää puheenvuoronsa aikana, olisi sen analysoimisen kannalta hyödyllistä esimerkiksi tietää, millaisia funktioita skrollaamisella ylipäätään on.

Tutkimuksen soveltaminen on myös erilaista kokoelmapohjaisissa yhteen genreen kytkeytyvissä tutkimuksissa ja multimediaalisuuteen pureutuvissa tapaustutkimuksissa, jotka tukeutuvat monipuoliseen aineistoon. Kokoelmapohjaisissa tutkimuksissa soveltaminen voi liittyä siihen, miten jokin toiminto olisi tarkoituksenmukaisinta tuottaa tai siihen, miten jokin tietyn genren voisi organisoida. Esimerkiksi Markman (2009) tutkimuksessaa chat-pohjaisten kokousten aloituksista ja lopetuksista esittää, että hänen analysoimiaan vuorovaikutusongelmia voisi lieventää ottamalla käyttöön selkeämpi kokousagenda. Multimediaalisia organisaatiokäytänteitä tutkittaessa myös soveltamismahdollisuudet kytkeytyvät nimenomaan tutkittaviin organisaatiokäytänteisiin. Jos tutkija pystyy osoittamaan, millainen rooli eri medioilla ja niihin kytkeytyvillä vuorovaikutuskäytänteillä on organisaatiokäytänteiden ja sitä kautta organisaation tavoitteiden toteuttamisessa, hän voi myös pohtia sitä, millä tavoin mediat, muun muassa digitaaliset teknologiat, voitaisiin saada parempaan ja tehokkaampaan käyttöön. Tällaiset pohdinnat ovat relevantteja sekä tutkimuksen kohteena olevan organisaation kannalta että yleisemminkin. Esimerkiksi tässä esitellyn tapauksen suhteen pohdimme organisaation edustajien kanssa sitä, miten osallistujien kommentit voitaisiin ottaa organisoidummin huomioon, tulevan toiminnan ja vuorovaikutuksen pohjaksi. Tällainen soveltaminen edellyttää yhtäältä diskurssintutkimuksellista näkemystä vuorovaikutuksen organisoitumisesta ja mahdollisuuksista eri medioissa ja niiden välillä, toisaalta riittävää ymmärrystä myös siitä, 
172 DIGITAALINEN DISKURSSI TYÖELÄMÄN KONTEKSTISSA -

MENETELMÄLLISIÄ HAASTEITA JA RATKAISUEHDOTUKSIA

mihin organisaatioiden käytänteillä pyritään, jotta voidaan saavuttaa keskusteluyhteys tutkijoiden ja organisaatioiden toimijoiden välillä. Parhaimmillaan se toimii, kun tutkimuksen tavoitteita on mietitty alusta asti yhdessä.

\section{Kirjallisuus}

Arminen, l., C. Licoppe \& A. Spagnolli 2016. Respecifying mediated interaction. Research on Language and Social Interaction, 49 (4), 290-309. https://doi.org/10.1080/08351813.2016.1234614

Arminen, I \& P. Poikus 2009. Diagnostic reasoning in the use of travel management system. Computer Supported Cooperative Work, 18, 251-276.

Asmuß, B. 2015. Multimodal perspectives on meeting interaction. Teoksessa J. Allen, N. Lehmann-Willenbrock \& S. Rogelberg (toim.) The Cambridge handbook of meeting science. Cambridge: Cambridge University Press, 247-276.

Asmuß, B. \& S. Oshima 2012. Negotiation of entitlement in proposal sequences. Discourse Studies, 14 (1), 67-86. https://doi.org/10.1177/1461445611427215

Asmuß, B. \& S. Oshima 2018. Mediated business: living the organizational surroundings introduction. Culture and Organization, 24 (1), 1-10. https://doi.org/10.1080/14759551.2017.1387965

Boczkowski, P.J. \& W.J. Orlikowski 2004. Organizational discourse and new media: a practice perspective. Teoksessa D. Grant, C. Hardy, C. Oswick \& L. Putnam (toim.), The Sage handbook of organizational discourse. Lontoo: Sage, 359-378.

Bucher, T. \& A. Helmond 2018. The affordances of social media. Teoksessa J. Burgess, A. Marwick \& T. Poell (toim.) The Sage handbook of social media. Lontoo: Sage, 233-253.

Darics, E. 2010. Politeness in computer-mediated discourse of a virtual team. Journal of Politeness Research, 6 (1), 129-150.

Darics, E. 2015. Introduction: business communication in the digital age - fresh perspectives. Teoksessa E. Darics (toim.), Digital business discourse. Basingstoke: Palgrave Macmillan, 1-16.

Darics, E. 2016. Digital media in workplace interaction. Teoksessa A. Georgakopoulou \& T. Spilioti (toim.) The Routledge handbook of language and digital communication. Lontoo: Routledge, 197-211.

Fairclough, N. 2003. Analysing discourse. Textual analysis for social research. Lontoo: Routledge.

Hutcbhy, I. 2001. Technologies, texts and affordances. Sociology 35 (2), 441-456.

Jokinen, A., K. Juhila \& E. Suoninen 1993. Diskurssianalyysin aakkoset. Tampere: Vastapaino.

Kress, G. \& T. van Leeuwen 2001. Multimodal discourse. The modes and media of contemporary communication. Lontoo: Hodder Education.

Llewellyn, N. 2010. On the reflexivity between setting and practice: the 'recruitment interview'. Teoksessa J. Hindmarsh \& N. Llewellyn (toim.). Organisation, interaction and practice. Studies in ethnomethodology and conversation analysis. Cambridge: Cambridge University Press, 74-95.

Markman, K. 2006. Computer-mediated communication. The organization of talk in chat-based virtual team meetings. Unpublished doctoral dissertation. University of Texas at Austin.

Markman, K. 2009. "So what shall we talk about": openings and closings in chat-based virtual meetings. Journal of Business Communication, 46 (1), 150-170. 
Meredith, J. 2017. Analysing technological affordances of online interactions using conversation analysis. Journal of Pragmatics 115, 42-55.

Nielsen, M.F. 2012. Using artifacts in brainstorming sessions to secure participation and decouple sequentiality. Discourse Studies 14 (1), 87-109.

Nissi, R. \& P. Pälli 2020. Textual artefacts at the centre of sensemaking: the use of discursivematerial resources in constructing joint understanding in organisational workshops. Discourse Studies, 22 (2), 123-145. https://doi.org/10.1177\%2F1461445619893794

Oittinen, T. \& A. Piirainen-Marsh 2015. Openings in technology-mediated business meetings. Journal of Pragmatics 85, 47-66.

Orlikowski, W.J. \& S.V. Scott 2016. Digital work: a research agenda. Teoksessa B. Czarniawska (toim.) A research agenda for management and organization studies. Northampton, MA: Edward Elgar Publishing, 88-96.

Pälli, P \& E. Lehtinen 2014. Making objectives common in performance appraisal interviews. Language \& Communication 39, 92-108.

Sellen, A. \& R, Harper. 2002. The myth of the paperless office. Cambridge: The MIT Press.

Seppänen, E. 1997. Vuorovaikutus paperilla. Teoksessa L. Tainio (toim.), Keskustelunanalyysin perusteet. Tampere: Vastapaino, 18-31.

Skovholt, K. \& J. Svennevig 2013. Responses and non-responses in workplace emails. Teoksessa S. Herring, D. Stein \& T. Virtanen (toim.), Pragmatics of computer-mediated communication. Berliini: Mouton de Gruyter, 589-611.

ten Have, P. (2007). Doing conversation analysis. A practical guide. 2. p. Lontoo: Sage.

Tutkimusta on rahoittanut Suomen Akatemia (hanke 322733) 